\title{
Organizing Experiential Learning Activities for Development of Core Competences of Technical Students in Vietnam
}

\author{
Oanh Duong Thi Kim
}

Ho Chi Minh City University of Technology and Education, Vietnam

Copyright@2019 by authors, all rights reserved. Authors agree that this article remains permanently open access under the terms of the Creative Commons Attribution License 4.0 International License

\begin{abstract}
The transition towards a sustainable economy has given a new term "green competences". Green competences build upon the foundation of core competences including literacy, numeracy, communication, teamwork and problem-solving - which along with awareness of environmental issues and entrepreneurship, facilitate lifelong learning and adaptability to environmental change (Marsden, Medhurst \& Irving, 2014) [1]. Organizing experiential learning activities is not new to the learning environment in higher education institutions in the world. However, it would be a new approach to some cultures like Vietnam, where most of students are not familiar with studying in proactive and experiential ways. Experiential learning activities provide students with opportunities to self - construct their competences from experience. This article describes a brief theoretical approach to core competence and experiential learning activities (Project-Based Learning, Learning Games) for developing core competencies (problem-solving, teamwork) of technical students at Ho Chi Minh City University of Technology and Education (HCMUTE) in Vietnam. In addition, qualitative (observation and interview) and quantitative methods were used to describe a progression of improving core competences of technical students. Finally, minor suggestions for lecturers to develop core competences of technical students through organizing experiential learning activities by carefully considering a consistency of learning outcomes, teaching-learning activities and assessment according to the "Conceive Design Implement Operation" (CDIO) approach to engineering education at HCMUTE were given.
\end{abstract}

Keywords Core Competence, Experiential Teaching, Project Based Learning, Learning Games

\section{Introduction}

Experiential learning and the value of experiential learning have been proved by philosophers and scientist such as Confucius, Aristotle, Comenius, Rousseau, Locke, Hahn, Dewey, Kolb and so on. Beard \& Wilson (2006) [2] stated that learning from experience is one of the most fundamental and natural means of learning available to everyone. Students are more active and motivated in experiential learning. They engage closely together to deal with learning tasks associated with practical contexts. Their academic/professional and core competences are developed by learning from experience.

We are living in the Industrial Revolution 4.0 with the requirement of a massive transformation in employee competences and training. Employers are not just looking for technical competences to do the job but also equally looking for what experts call cognitive competences, social and behavioral competences such as teamwork, problem-solving, critical thinking, creative thinking and so on (Christian \& Magnusson, 2013) [3]. Core competences will be combined with technical or professional competences, enable an individual to fulfill a job (OECD) [4].

To meet the demand of the Industrial Revolution 4.0, higher education institutions must shift from the Teacher-Centered Teaching to Student-Centered Teaching. This transformation concentrates mainly on the learner, the learning process and organizing experiential learning activities related to dealing with real-world learning tasks to develop holistic competences of learners.

Ho Chi Minh City University of Technology and Education (HCMUTE) are the leading university in educating and training, engineers as well as technical and vocational teachers in Vietnam. Be deep awareness of the value of core competences of the engineer at the workplace in the near future and the shift toward the Student-Centered Approach in training, HCMUTE is coping with a big 
question: How to develop core competences of technical students through organizing experiential learning activities efficiently? This paper offers a selected review of literature on core competence and experiential learning before describing sample experiential learning activities designed to develop core competences of technical students at HCMUTE.

\section{A brief Literature Review of Core Competence and Experiential Learning}

\subsection{Competence and Core Competence}

The term "competence" is a very popular concept to express an ability to do something successfully or efficiently. Deißinger \& Hellwig (2011) [5] stated that Competence (in the British context) or competency (in the Australian context) is derived from Latin - Competentia meaning agreement or conjunction. Competence is not just knowledge and skills but an ability to meet complex demands by drawing on and mobilizing psychosocial resources (including skills and attitudes) in a particular. According to Hoskins \& Crick (2008) [6], a competence is best described as a complex combination of knowledge, skills, understanding, values, attitudes and desire which lead to effective, embodied human action in the world, in a particular domain.

"Core competence" is built up based on distinguishing the term "competence" in two groups: core competence and technical competence (OECD, 2014) [4]. Core competence can be defined as personal attributes or underlining characteristics, which combined with technical or professional skills, enable the delivery of a role/job. Core competences do not define individuals' technical roles and accountabilities, nor do they include the technical skills necessary to do the jobs. On the contrary, technical competences cover the various fields of expertise relevant to the specific work (OECD, 2014) [4]. Core competences are closely related to technical competences. The development of core competences has an effect on technical competences and vice versa (Ry \& Que, 2015).

Ry and Que (2015) [7] classified core competences in 3 groups:

- Autonomous activity and personal development competences comprise of self-study, Problem-solving, Creative thinking and so on.

- Social competences contain Communication, Teamwork and so on.

- Tool competences consist of language, computer, calculate and so on.

Study on Assessment and Teaching of 21st Century Skills (ATC21S), Griffin, McGaw and Care (2012) [8] distinguished core competences according to the KSAVE (Knowledge Skills Attitudes Values Ethics) framework listed below:

- Ways of thinking: Creativity and innovation; Critical thinking, Problem-solving; Learning to learn and meta cognition.

- Ways of working: Communication; Collaboration and Teamwork.

- Tools for working: Information literacy, Information, Communications and Technology (ICT) literacy.

- Living in the real world: Citizenship, local and global; Life and career; Personal and social responsibility.

The Partnership for $21^{\text {st }}$ Century Learning (P21) (2015) [9] developed the Framework for $21^{\text {st }}$ Century Learning with knowledge, skills and expertise students must master to succeed in work and life. The framework comprises of 4 categories:

- Learning and Innovation skills: Creativity and Innovation; Critical thinking and Problem solving; Communication and Collaboration.

- Information, Media and Technology skills: Information literacy; Media literacy; ICT literacy.

- $\quad$ Life and Career skills: Flexibility and Adaptability; Initiative and Self-direction; Social and Cross-Cultural skills; Productivity and Accountability; Leadership and Responsibility.

HCMUTE has implemented the engineering training programmes developed according to the CDIO approach since the school year 2012-2013. HCMUTE's training programmes provide students with a comprehensive set of technical and core competences by engineering practice through the entire lifecycle of engineering processes, products, and processes. Students develop core competences such as problem-solving, creativity, collaboration and teamwork during the engineering practice through experiencing, learning by doing or hands-on.

To sum up, core competences have been drawn attention by scholars and organizations. The international discussion on core competences stated that mastering core competences help students be successful in work and life. Respecting the international discussion on core competences and based on requirements of HCMUTE's engineering training programmes, this article focuses on developing teamwork and problem-solving of technical students at HCMUTE.

\subsection{Experiential Learning}

"Experience" is a familiar word to know things around through doing or practicing. In Oxford Learner's Dictionaries, "experience" means the knowledge and skill that people have gained through doing something for a period of time; the process of gaining this; the things that 
have happened to you that influence on the way you think and behave. In the philosophy, it means an internal action from heart connected with life and existence (Dongmei Sheng, 2016) [10].

From the time of the first teachers, it has been recognized that an important relationship exists between experience and learning (Knutson, 2003) [11]. The perspective of learning by doing, practicing, is touching occurring from the ancient time. There is a common adage attached to experiential learning: "Tell me and I will forget, show me and I may remember, involve me and I will understand" (Confucius cirea 450 BC). Around 350 BCE, Aristotle also stated the value of learning by doing: "for the things we have to learn before we can do them, we learn by doing them".

In the early decades of the 20th century, Dewey (1938) [12] stressed the importance of experience in education. According to Dewey, there is an intimate and necessary relation between the processes of actual experience and education.

Based on Dewey's work and along with other notable theorists such as Lewin, Piaget, Rogers, and James, Kolb developed more deeply the modern theory of experiential learning in 1970s. According to Fry and Kolb (1979) [13], experiential learning theory provides an integrative framework for understanding the teaching-learning process. Kolb (1984) [14] believed that learning is the process whereby knowledge is created through the combination of grasping and transforming experience. The Experiential Learning Cycle was created by Kolb with four stages of comprising of Concrete Experience, Reflexive Observation, Abstract Conceptualization and Active Experimentation. Stages of the Experiential Learning Cycle provide teachers and students with a better understanding of facilitating learning more effectively through the experiential learning process.

In brief, learning form experience is one of the most fundamental and natural means of learning available to everyone (Beard \& Wilson, 2006) [2]. In its simplest way, experiential learning means learning from experience or learning by doing (Lewis \& Williams, 1994) [15].

Experiential learning is implemented through various activities, including action learning (Marquardt, 2007 \&
Silberman, 2006) [16, 17], learning games (Silberman, 2006 \& Ukens, 2007) [17, 18], field trip (Lei Li, Fan Cheung, Ning Wang, Lixing Lao, Yibin Feng, 2016) [19], Project-Based Learning (PBL) (Lee Hong Sharon Yam \& Rossini, 2010 and Efstratia, 2014) [20, 22] and so on. Experiential learning activities enhance students deeply understanding of concepts as well as the gateway to develop their competences.

In the classroom, PBL and learning games are main experiential learning activities to help students develop their technical and core competences by dealing with real-world learning tasks. PBL engages students in exploring important and meaningful questions through a series of investigations and collaborations (Krajcik, Czerniak \& Berger, 1999) [21]. PBL connects students' experiences with school life and provokes serious thinking as students acquire new knowledge (Efstratia, 2014) [22]. The main objectives of PBL are to expose students to experiential learning and provide them with an overview of professional activities (Lee Hong Sharon Yam \& Rossini, 2010) [20].

According to Seidel, Aryeh \& Steinberg (2002) [23], PBL is most often characterized by:

- A series of activities with a sustained focus over time and linked to an outcome of significance - a performance, product, or service that is highly valued by the students as well as a broader community.

- A group effort that often moves beyond the walls of the classroom or after school, into the community for research, internships, presentations and so on.

- Clear learning goals that often embrace academic, social, and metacognitive dimensions simultaneously.

- Assessment that is ongoing with frequent opportunities for students to receive and provide feedback as the work is developing as well as final evaluation from peers, instructors, and the public, including self-assessment.

Based on the characteristics of PBL and a general process of learning organization, this paper proposes the process of organizing PBL with 5 steps in the Figure 1 below: 

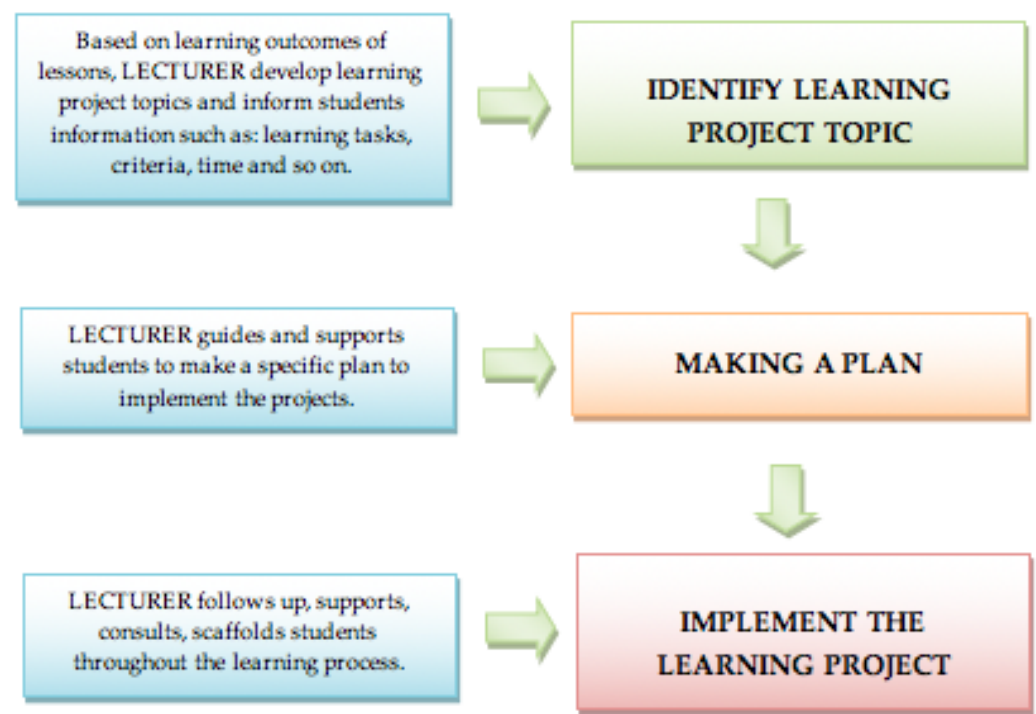

LECTURER listens to students' presentations and take notes.
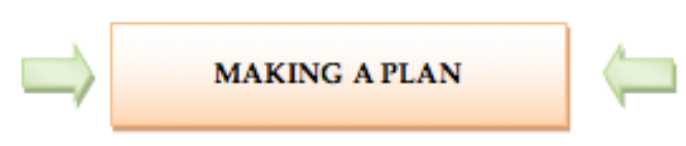

\section{$\Rightarrow$}
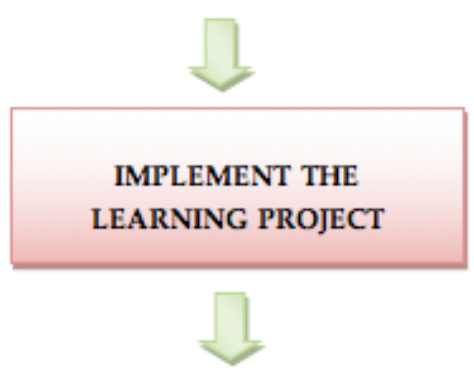
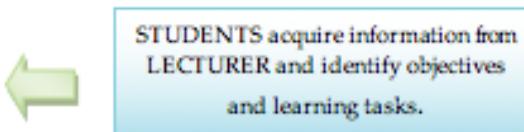
and learning tasks.

STUDENTS make a specific plan to implement the learning project: time, identify tasks, assign tasks, recourses expected outcomes
STUDENTS implement the learning project according to the plan: collect and process information, propose measures, select the best appropriate measure, implement the measure, test, and regulate
LECTURER design Rubrics. LECTURER assesses and encourage students do self and peer-assessment. LECTURER sums up and recaps
PRESENT THE RESULTS
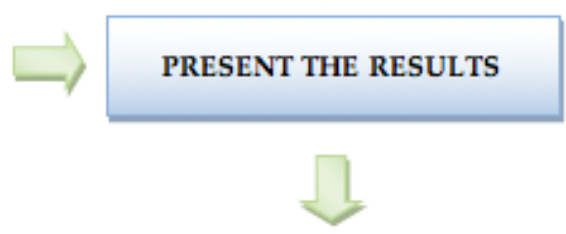

\section{ASSESS THE RESULTS}
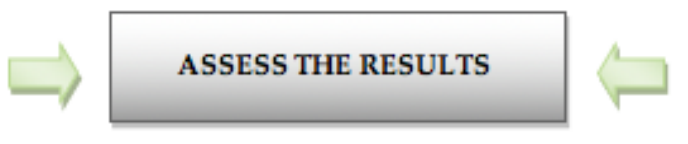

STUDENTS do self and peerassessment.

Figure 1. The process of organizing PBL

In short, PBL is a dynamic approach to teaching in which students explore real - world problems and challenges. PBL helps students deepen their understanding of content while working collaboratively on complex real-world problems (Edward, 2015) [24].

Not only PBL but learning games are also applied to enhance the experiential learning process of students. Play has been recognized a critical part of human being development as children start learning through play. A learning game often requires such actions as solving problems and puzzles, analyzing information, making self-disclosure and refers to the objective of improving the players' level of competency in particular areas (Ukens, 2007) [18]. So, it provides learners with opportunities to overcome an obstacle with real feelings of success and real learning (Ukens, 2007) [18] as well as to experience the total content before discussing the parts (Silberman \& Biech, 2015) [25].

The process of organizing learning games was proposed by this paper comprising of six steps listed below:

- Lecturer develops learning games engaging with learning tasks and inform learning tasks to the class.

- $\quad$ Lecturer divides the class into small groups to solve learning tasks.

- $\quad$ Students solve learning tasks through playing games.
- Lecturer supports and consults students when students collaborate to solve learning tasks through playing games.

- Student's present results, the other group give feedback.

- Lecturer and students co-make the judgments according to assessment tools.

Students are considered to be more relaxed and motivated when they learn how to deal with learning tasks through playing games. Chen (2005) [26] summed up benefits of using games in nine points:

- Games are learner centered.

- $\quad$ Games promote communicative competence.

- Games create a meaningful context for language use.

- Games increase learning motivation.

- Games reduce learning anxiety.

- Games integrate various linguistic skills.

- Games encourage creative and spontaneous use of language.

- Games construct a cooperative learning environment.

- $\quad$ Games foster participatory attitudes of the students.

In the trend of shifting from Teachers-Centered Approach to Students-Centered Approach, experiential learning activities such as PBL and Learning Games play 
very crucial roles in developing competences of learners. Lecturers are encouraged to apply widely them in higher education institutions to cater for the development of students' academic/professional and core competences through doing/practicing/touching/solving the complex real-world problems. So, we applied Learning Games and PBL to develop some core competences of technical students at HCMUTE.

\section{Development of Core Competences of Technical Students through Organizing Experiential Learning Activities at HCMUTE}

\subsection{Overview of Making a Lesson Plan for Organizing Experiential Learning Activities to Develop Technical Students' Core Competences and Assessment Tools of a Progress of Their Core Competences}

Based on the brief review of core competence, experiential learning above, we develop diversified experiential learning activities of a subject named System Thinking to develop core competences of technical students at HCMUTE.

System Thinking is one of subjects belonging to the general knowledge of the CDIO training curriculum implementing at HCMUTE since the school year of 2012 2013. System Thinking involves a holistic approach, taking into account as many different factors as possible to avoid interpreting problems from a single point of view (Kriz, 2008) [27]. After completing this subject, technical students are expected to be able to apply the perspective of system thinking in building a green specific system and develop some core competences such as problem solving, teamwork, critical thinking, and creative thinking. System Thinking concentrates on developing technical students' interest and creativity through everyday experiences and investigations that are based on inquiry and hands-on.

PBL and learning game activities were built on to encourage students to hands-on or learn by doing. These experiential learning activities are described more detail in the Table 1 below:

Table 1. Lesson plan for experiential learning activities of System Thinking subject

\begin{tabular}{|c|c|c|c|c|}
\hline Learning Outcomes & Contents & $\begin{array}{c}\text { Experiential Learning } \\
\text { Activities }\end{array}$ & Assessment & Intended results \\
\hline \multicolumn{5}{|c|}{ Chapter 1: Overview of System } \\
\hline $\begin{array}{ll}- & \text { Identify traits of a } \\
\text { - } & \text { system. } \\
\text { Describe a system. } \\
\text { - } \quad \text { Develop a system. } \\
\text { Develop core } \\
\text { competences such as } \\
\text { problem-solving, } \\
\text { teamwork. }\end{array}$ & $\begin{array}{ll}\text { 1. } & \begin{array}{l}\text { Definition of a } \\
\text { system }\end{array} \\
\text { 2. } & \text { Decribe a system } \\
\text { 3. } & \text { Analyze and design } \\
\text { a system }\end{array}$ & $\begin{array}{l}\text { Project-Based Learning } \\
\text { activity: Develop a } \\
\text { system (a bridge, a house, } \\
\text { a device and so on) by } \\
\text { recycling waste materials. }\end{array}$ & $\begin{array}{l}\text { Rubrics of } \\
\text { problem-solving } \\
\text { and teamwork }\end{array}$ & $\begin{array}{l}\text { - A developed system } \\
\text { by recycling waste } \\
\text { materials. } \\
\text { Core competences } \\
\text { of technical } \\
\text { students will be } \\
\text { developed. }\end{array}$ \\
\hline \multicolumn{5}{|c|}{ Chapter 2: Thinking and Technical Thinking } \\
\hline \multirow{2}{*}{$\begin{array}{l}\text { Apply think } \\
\text { manipulations in } \\
\text { solving real-world } \\
\text { problems. } \\
\text { Apply the structure of } \\
\text { technical thinking to } \\
\text { develop a system. } \\
\text { Develop core } \\
\text { competences such as } \\
\text { problem-solving, } \\
\text { teamwork. }\end{array}$} & $\begin{array}{ll}\text { 1. } & \text { Overview of } \\
\text { thinking: } \\
\text { - } \\
\text { Definition of } \\
\text { thinking } \\
\text { - } \quad \text { Traits of thinking } \\
\text { Thinking } \\
\text { manipulations }\end{array}$ & $\begin{array}{l}\text { Learning games activity: } \\
\text { Form specific shapes as } \\
\text { given patterns by using } \\
\text { seven blocks of wood in } \\
\text { the least amount of time. }\end{array}$ & $\begin{array}{l}\text { Rubrics of } \\
\text { problem-solving } \\
\text { and teamwork }\end{array}$ & $\begin{array}{l}\text { - A specific shape as } \\
\text { a given pattern in } \\
\text { the least amount of } \\
\text { time. } \\
\text { - Core competences } \\
\text { of technical } \\
\text { students will be } \\
\text { developed. }\end{array}$ \\
\hline & $\begin{array}{ll}\text { 2. } & \text { Technical Thinking: } \\
\text { - } & \text { Definition of } \\
& \text { technical thinking } \\
\text { - } & \text { Traits of technical } \\
& \text { thinking } \\
\text { - } & \text { Structure of } \\
& \text { Techinical Thinking } \\
\end{array}$ & $\begin{array}{l}\text { Project-Based Learning } \\
\text { activity: } \\
\text { Build a tower by using } \\
200 \text { straws and scotch } \\
\text { tapes. }\end{array}$ & $\begin{array}{l}\text { Rubrics of } \\
\text { problem-solving } \\
\text { and teamwork }\end{array}$ & $\begin{array}{l}\text { A tower built by } \\
200 \text { straws and } \\
\text { scotch tapes. } \\
\text { Core competences } \\
\text { of technical } \\
\text { students will be } \\
\text { developed. }\end{array}$ \\
\hline \multicolumn{5}{|c|}{ Chapter 3: Creative thinking methods to develop sustainable development systems } \\
\hline $\begin{array}{l}\text { Apply creative thinking } \\
\text { methods to develop a } \\
\text { sustainable development } \\
\text { system. }\end{array}$ & $\begin{array}{ll}\text { 1. } & \text { Mind map method } \\
\text { 2. } & \text { Five W and One H } \\
\text { method } \\
\text { 3. } & \begin{array}{l}\text { Cause and Effect } \\
\text { diagram method }\end{array} \\
\text { 4. } & \text { Focal object method } \\
\text { 5. } & \text { DO IT method } \\
\text { 6. } & \text { Six thinking hats }\end{array}$ & $\begin{array}{l}\text { Project-Based Learning } \\
\text { activity: Propose } \\
\text { measures to improve a } \\
\text { system according to the } \\
\text { system thinking } \\
\text { perspective through } \\
\text { applying the focal object } \\
\text { method. }\end{array}$ & $\begin{array}{l}\text { Rubrics of } \\
\text { problem-solving } \\
\text { and teamwork }\end{array}$ & $\begin{array}{l}\text { An improved system } \\
\text { according to the system } \\
\text { thinking perspective by } \\
\text { proposed measures of the } \\
\text { focal object method. }\end{array}$ \\
\hline
\end{tabular}


Students participating in small groups not only solve learning tasks, but also learn how to relate well to others, to co-operate and to resolve conflicts within their team. To deal with the problem, students have to identify the problem, collect and analyze information, develop plans, implement proposed solutions and finally evaluate the results. These activities are performance criteria of teamwork and problem-solving competence.

Core competences are quantified by rubrics of "Problem-solving competence" and "Teamwork competence" developed by lecturers as well as students. Rubrics comprise of performance criteria, rating scale for performance levels and indicators for each performance level. Performance levels consists of "Exceeds expectations", "Meets expectations", "Progressing" and "Not there yet".

To develop rubrics, based on learning outcomes of the subject, lecturers develop criteria by specifying the skills, knowledge, and/or behaviors and limiting the characteristics that are most important to the assessment. Performance levels, indicators and points of each performance level are identified. Total number of points received divided by total possible points is total score of rubrics. Then, students try on rubrics and give their own feedback on the reliability, validity and usefulness of rubrics. Lecturers revise rubrics carefully according to students' feedback. Completed rubrics are informed publicly to students parallel with organizing experiential learning activities.

After completing experiential learning activities, students receive rubrics made judgment by lecturers and classmates. Rubrics with comments of lecturers and classmates are combined into a portfolio. The portfolio of each student indicates clearly a progress of students' core competences or not compared with before participating in experiential learning activities.

\subsection{Discussion on a Progress of Core Competences of Technical Students by Participating in Experiential Learning Activities at HCMUTE}

Based on the process of organizing PBL and learning games above, three PBL and one learning game were implemented to provide students with opportunities to develop their academic and core competence. In the school year of 2017 - 2018, there were 210 freshmen and sophomore students in five classes taking part in studying System Thinking. In every class, students were divided into small groups to conduct PBL and learning game activities. Some outstanding examples of organizing experiential learning activities for sustainable development of core competences of technical students at HCMUTE are illustrated in more detail.

To link closely the knowledge of analyzing/designing a system with building a real system and developing problem-solving and teamwork competences, students were required to implement the learning project: "Develop a system (a bridge, a house, a device and so on) by recycling waste materials". The allowed time was one week. The team size is $4-6$ students. The project was completed with many diversified practical systems developed by recycling waste materials such as a smart house, a lifted bridge, a boat, and so on.

A group of students developed a smart house following the requirement of the learning project. Smart houses controlled by smart phones are not new in the modern life. However, using waste materials to create a smart house controlled by smart phones was a really new learning experience of students at HCMUTE. To deal with the learning task students identified the problem through answering questions: How the system developed? Which materials are used to develop the system? What is the system for? Students decided to develop the the smart house by using bamboo sticks, bulbs and wires and a smart phone. Students collected information to clarify the identified problem and propose solutions. Advantages and disadvantages of each solution as well as conditions of the implementation were analyzed carefully. Then the best appropriate solution for developing the system was chosen by members. Students implemented the selected solution, tested, regulated and presented the product in the class. The light system of the recycled house was illuminated by the smartphone.

With this experiential learning activity, not only did every student do the assigned task, but they also co-operated with the other members to revise and complete the system. Interviewing members of the group about obstacles in the process of implementing the learning project, students shared that they coped with difficulties when uniting different ideas. However, they learned how to work together and give critical feedbacks to develop the system.

Observing the performance of students and based on rubrics of problem solving and teamwork indicated that the total score of rubrics of students achieved the "exceeds expectations" level.
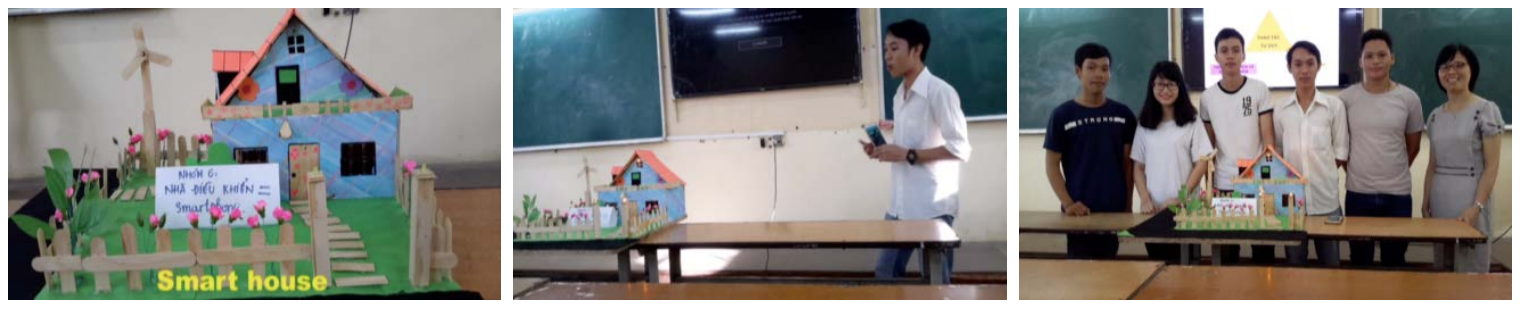

Figure 2. The smart house developed by recycling waste materials 
To experience the total content of "thinking manipulations" before discussing about specific thinking manipulations, students were required to play a puzzle game: "Form specific shapes as given patterns by using seven blocks of wood in the least amount of time”. Every group of 4-6 students co-operated to analyze/synthesize/compare the given outline with the puzzle's seven wood shapes. Each group presented activities experiencing to play the game. Then, the lecturer combined experiential activities with each thinking manipulation. According to lecturer's guidelines, students discussed about thinking manipulations' characteristics and how to apply them in constructing a specific system. Finally, specific thinking manipulations were summarized by the lecturer and students. In this experiential learning game, performance areas of problem-solving competence and teamwork competence were also quantified by rubrics.

Successful groups used activities as thinking manipulations (analyze, synthesis, compare, generalize) to form shapes through identifying the puzzle problem, analyzing/comparing the relationship between the given outline and a concrete relationship of seven wood shapes, forming shapes and evaluating results. Members discussed about the puzzle problem and ways of forming shapes in harmony. Those groups that did not follow the same process were often not successful in forming shapes in the least amount of time. Students in unsuccessful groups revealed that each member played according to their own way. They did not listen to others to identify the problem before forming shapes.

Applying the learning game in teaching the content "thinking manipulation" revealed that students could self-construct knowledge on "thinking manipulations" and hands-on to develop performance areas of problem solving and team work. However, a proportion of students still faced challenges in identifying problems in a specific context and dealing with conflicts in small groups.

To apply the theoretical point of structure in technical thinking to developing a sustainable system, students were required to tackle the learning task: "Build a tower from 200 straws and scotch tapes". Working in teams of 4-6, students were allowed 30 minutes to complete the task. The criteria for success was the durability (length of time before collapse) of the structure. Results were quantified by rubrics.

Careful observation during the learning process revealed that students in every groups were so excited and motivated to build the tower. They firstly discussed the pattern of the tower and selected the most relevant proposal. Members in each group were assigned to do their own parts. They related well to others to complete their work. In general, most of students in our class did not meet any difficulties in co-operating with others to identify and tackle the problem. They got in touch closely together to build the system. The total core of rubrics achieved the "exceeds expectations" and "meet expectation" levels.

The final experiential learning activity of the subject required students to implement the project in one week: "Propose measures to improve a system according to the system thinking perspective through applying the focal object method". Students were given an opportunity to decide everything concerning with a system needed to be improved by themselves:

- Students are encouraged to find their partners (maximum three students per a group) to do the project.

- Students identify the problem and propose solutions to improve a system according to the system thinking perspective.

- Students self-assess and peer-assess their results.
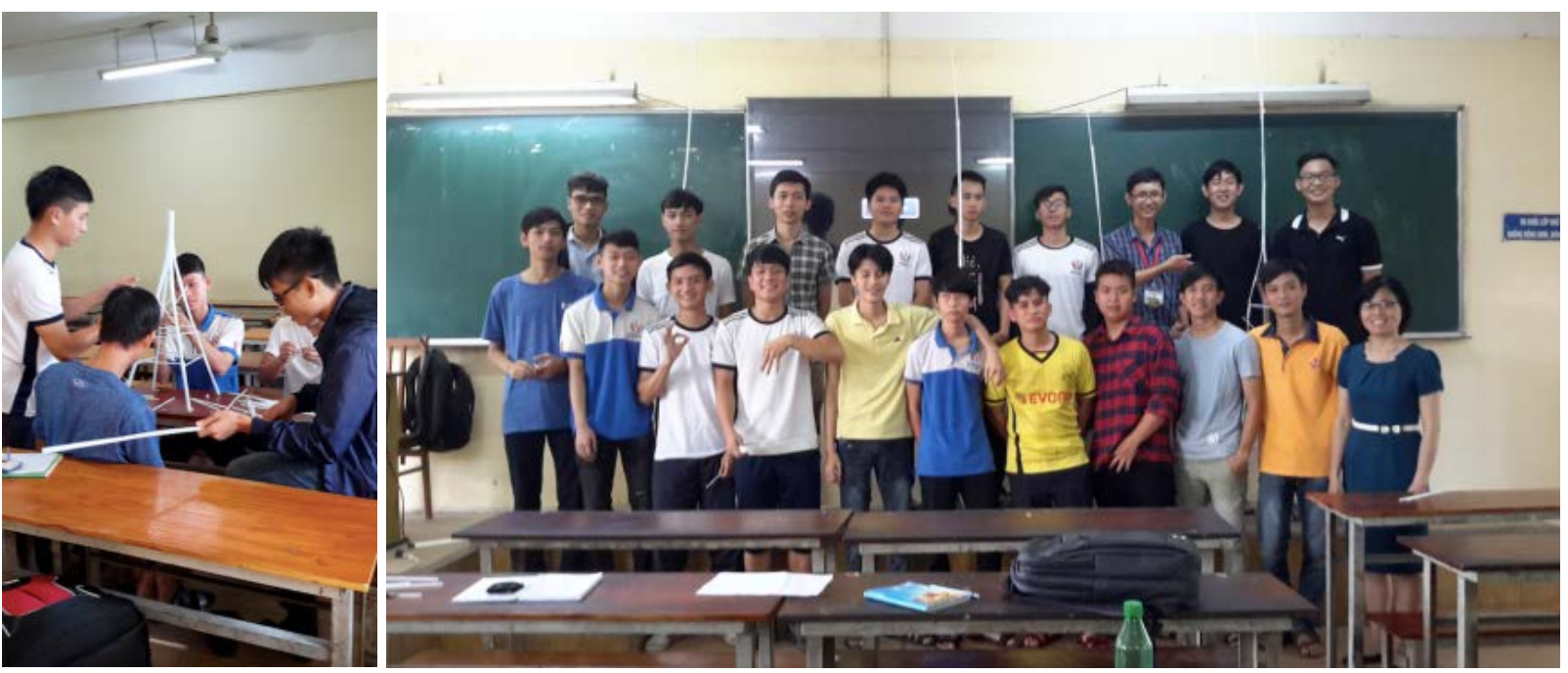

Figure 3. Build a tower from 200 straws and scotch tapes 
To meet the requirement of the learning task, partners were chosen by every student to form small groups. Interviewing students on group work activities indicated that they were satisfied about their partners because each partner tried the best to complete the project. They listened to each other and discussed openly to find feasible solutions for improving the selected system.

Working in a very positive atmosphere, members in small groups discussed about advantages and disadvantages of systems are improved to become green/sustainable systems as the system thinking perspective. Students applied the focal object method to get ideas for improving the system with six steps (Phan Dung, 2010) [28]:

- $\quad$ Select the object focal point for improvement

- $\quad$ Select random object focus

- $\quad$ List the characteristics of the selected object

- $\quad$ Combine the characteristics of the selected object to the object focal point

- $\quad$ Develop the idea from a combination of in step 4 is based on the free association

- $\quad$ Evaluation and selection of viable ideas

Based on the above process, many improved systems were presented in our class such as a studying table, a pen, a pesticide spray tank, a dustbin and so on. The common tendency of improving systems is to integrate technology to automatize or make them become smarter and more familiar. Improved systems are clear and adequate evidences for the sustainable development of technical students' core competences.

In brief, PBL and learning games are two significantly experiential learning activities organized to provide students with opportunities to practice and develop their core competences sustainably. So hands-on and learning by doing have brought students the sustainable development in terms of academic competence and core competence.

\section{Conclusions}

Organizing experiential learning activities is not a new teaching approach in higher education institutions. However, it is relatively new and valuable approach in the Vietnamese universities context where lecturers and students seem to be familiar with teaching and learning in the passive way. Experiential learning activities such as PBL and learning games enhance students to study in the proactive way. They provide students with opportunities and challenges to self - construct knowledge, skills, attitude and so on from experience for their lifelong learning.

Applying experiential learning activities requires lecturers and students to change their mindset of teaching and learning ways. Their actions should be shifted from the Teacher-Centered Approach to the Student-Centered
Approach. Instead of concentrating only on delivering lessons in person and requiring students to remember knowledge, learning tasks associated with practical and professional contexts should be developed to bring students opportunities to study in the proactive and experiential ways. Lessons should be transferred to students via the online learning management system. Reading and studying lessons should be implemented seriously by students before going to the class. In the class, students self-synthesize vital theoretical knowledge points by discussing with their lecturer and classmates. Students actively learn how to listen to others and share ideas in group work activities. Students are more positive and responsible when they try their best to do hands-on or learn by doing.

Experiential learning activities also should be integrated into learning outcomes, teaching methods and assessment. The consistency among these factors will support students to develop their core competences gradually during the learning process. Most of Vietnamese students prefer studying solo than collaborating with others. In our class, they were encouraged to overcome the psychological barrier to implement learning projects or the learning game successfully. Their core competences were developed gradually and sustainably through organizing various experiential learning activities at HCMUTE.

\section{REFERENCES}

[1] G. P. Marsden, J. Medhurst, P. Irving. The case for a global green skills training action plan. In OECD/Cedefop: Greener Skills and Jobs. OECD Green Growth Studies. OECD Publishing. 2014. Online: http://dx.doi.org/10.1787/978926 4208704-en

[2] C. Beard \& J.P. Wilson. Experiential learning - A Best Practice Handbook for Educators and Trainers (Second edition). Kogan Page. London and Philadelphia. 2006.

[3] W. J. B. Christian \& R. B. Magnusson. Vietnam Development Report 2014 - Skilling up Vietnam: Preparing the workforce for a modern market economy. Washington, DC, USA: The World Bank. 2013. Online: http://documents.worldbank.org/curated/en/2013/11/18556 434/vietnam-development-report-2014-preparing-work-for ce-modern-market-economy-vol-2-2-main-report

[4] Organization for Economic Cooperation and Development (OECD). Competency framework. 2014. Online: http://www.oecd.org/careers/competency_framework_en.p df

[5] A. T. Deißinger \& S. Hellwig. Structures and functions of Competency-based Education and Training (CBET): a comparative perspective. Human Capacity Development (HCD) for Vocational Education and Training (Mannheim). 2011.

[6] B. Hoskins \& R. D. Crick, Learning to learning and Civic Competences: different currencies or two sides of the same 
coin? 2008. Online: http://publications.jrc.ec.europa.eu/rep ository/bitstream/111111111/4954/1/reqno_jrc45123_learni ng\%20to\%20learn\%20and\%20civic\%20competence\%5B2 \%5D.pdf

[7] V. T. Ry \& D. X. Que. Competence based assessment of Physics in High school. Journal of Educational Sciences. The Vietnam Institute of Educational Sciences. No 123. 2015.

[8] D Griffin, P., McGaw, B. \& Care, E., Eds. Assessment and Teaching of 21st Century Skills. Dordrecht: Springer, 2012.

[9] The Partnership for 21st Century Learning (P21). P21 Framework Definitions. 2015. Online: http://www.p21.org/ storage/documents/docs/P21_Framework_Definitions_New _Logo_2015.pdf

[10] Dongmei Sheng. A case study of Experiential Teaching Method in EFL Listening. 6th International Conference on Electronic, Mechanical, Information and Management. 2016. Online: http://www.atlantis-press.com/php/download_paper .php?id=25853455

[11] S. Knutson. Experiential learning in Second - Language Classrooms. TESL Canada Journal. Volume 20. Issue 2. 2003. Online: http://teslcanadajournal.ca/index.php/tesl/arti cle/view/948/767

[12] J. Dewey. Education and experience. New York: Simon and Schuster. 1938.

[13] R. Fry \& D. Kolb. Experiential Learning Theory and Learning Experiences in Liberal Arts Education. New Directions for Experiential Learning. 6. p.79-92. 1979. Online: https://digitalcommons.unomaha.edu/cgi/viewconte nt.cgi?referer=https://www.google.com.vn/\&httpsredir=1\& article $=1123 \&$ context $=$ slceslgen

[14] D. Kolb. Experiential learning: Experience as the source of learning and development. New Jersey: Prentice-Hall. 1984.

[15] Linda H. Lewis, Carol J. Williams. Experiential learning: Past and Present. 1994, Online: http://www.sunyjcc.edu/file s/Experiential\%20Learning\%20-\%20Past \%20and\%20Pres ent.pdf

[16] M. Marquardt. Action Learning. In M. Silberman (Editor): The Handbook of Experiential Learning. John Wiley and Sons, Inc. 2007.

[17] M. Silberman. Active Teaching - A handbook of Techniques, Designs, Case Example and Tips (Third Edition). Pfeiffer. 2006.

[18] L. Ukens., Learning Games. In M. Silberman (Editor): The Handbook of Experiential Learning. John Wiley and Sons, Inc. 2007.

[19] Lei Li, Fan Cheung, Ning Wang, Lixing Lao, Yibin Feng. An experiential teaching and learning module Chinese Medicine: Field trip. International Education and Research Journal. Volume 2. Issue 9. 2016. Online: http://ierj.in/journal/index.php/ierj/article/view/440/416

[20] Lee Hong Sharon Yam \& P. Rossini. Effectiveness of Project - Based Learning as a strategy for Property Education. Pacific Rim Property Research Journal. Vol 16. No 3. 2010. Online: http://www.prres.net/Papers/ PRPRJ_No_3_2010_Yam.pdf
[21] J. Krajcik, C. Czerniak, C. Berger. Teaching Science: A Project-Based Approach. McGraw-Hill College. New York. 1999.

[22] D. Efstratia. Experiential education through project-based learning. 2014. Online: http://www.sciencedirect.com/scien ce/article/pii/S1877042814054299

[23] S. Seidel, L. Aryeh, A. Steinberg. Project - Based and Experiential Learning in After - School Programming. 2002. Online: http://www.pearweb.org/research/pdfs/3\%20-\%20p roject-based.pdf

[24] Edward M. Reeve. Science, Technology, Engineering, \& Mathematics (STEM) is here to say. 2015. Online: http://www.stemedthailand.org/wp-content/uploads/2015/0 8/STEM-Education-is-here-to-stay.pdfNmnm

[25] M. Silberman, E. Biech. Active Training - A Handbook of Techniques, Designs, Case Examples and Tips. Hoboken. New Jersey: John Wiley \& Sons, Inc. 2015.

[26] Chen. I-Jung. Using Games to Promote Communicative Skills in Language Learning. The Internet TESL Journal. Vol. XI. No. 2. February 2005. Online: http://iteslj.org/Techniques/Chen-Games.html

[27] K. W. Kriz. A Systemic-Constructivist Approach to the Facilitation and Debriefing of Simulations and Games. 2008. Online: http://journals.sagepub.com/doi/pdf/10.1177/10468 78108319867

[28] Phan Dung. Review of Creativity methods. Tre Publishing House. Vietnam. 2010. 